\title{
Aplikasi Mengkudu Sebagai Sumber Antioksidan Untuk Mengatasi Stress Ayam Broiler Di Daerah Tropis
}

\section{Application of Noni Fruit Juice as Source of Antioxidants for Anti-stress on Broiler in Tropical Regions}

\section{E. Syahruddin, H. Abbas, E. Purwati, dan Y. Heryandi}

Fakultas Peternakan Universitas Andalas

Kampus Unand Limau Manis Padang, 25153

e-mail: erman_syahruddin@yahoo.co.id

(Diterima: 27 Desember 2010; Disetujui: 14 April 2011)

\begin{abstract}
The study was conducted to test the effects of antioxidants levels $(0,500,1000$ and 1500 ppm) in fruit juice noni for broiler response in different room temperature $\left(20^{\circ} \mathrm{C}, 26^{\circ} \mathrm{C}\right.$ and $\left.32^{\circ} \mathrm{C}\right)$. Research material consist of: 360 tail of two-week old broilers strains Acress Arbor. Research over the past eight weeks (from June 18, 2010 to August 13, 2010). The basic design CRD Split plot models of $3 \times 4$ and 3 replicates with 10 chickens for each box, as the main plot: Room temperature $\left(20: 26\right.$ and $\left.32^{\circ} \mathrm{C}\right)$, and Sub plot: level of antioxidants in the fruit juice noni (0:500:1000 and 1500 ppm). The data obtained were statistically analyzed using the SAS program package, and if it show any real effect followed by Duncans test/DMRT. Variables measured were feed consumption, feed conversion and levels of hormone thyroxine and fabrisius bursa weights of broiler. The results showed that fruit juice noni reduce heat stress in chickens by administering 500 ppm antioxidants of fruit juice noni in the drinking water of chickens that are kept at temperature of $26^{\circ} \mathrm{C}$ and 1000 ppm at a temperature of $32^{\circ} \mathrm{C}$ to increase levels of the hormone thyroxine, fabrisius bursa and feed consumption, feed conversion equal with controls.
\end{abstract}

Keywords: fruit juice noni, antioxidants, thyroxine, stress, broiler.

\section{PENDAHULUAN}

Indonesia sebagai negara tropis, memiliki suhu lingkungan yang cukup tinggi, dengan rataan suhu harian $31,32 \pm 1,22^{\circ} \mathrm{C}$ (maksimum) dan $22,44 \pm 1,48^{0} \mathrm{C}$ (minimum) (BPS, 2009), sedangkan menurut Charles (2002) suhu yang nyaman untuk memelihara broiler berkisar antara $18-22^{\circ} \mathrm{C}$. Suhu lingkungan yang tinggi menyebabkan cekaman panas atau stres pada broiler yang ditandai dengan menurunnya laju pertumbuhan, gangguan keseimbangan hormonal, menúrunnya kapasitas biosíntesis vitamin $\mathrm{C}$, dan hipertropi kelenjar adrenal, (Kuczynski, 2002; Borges et al., 2004; Aengwanich dan Simaraks, 2004). Cekaman panas atau heat stress merupakan respon yang timbul apabila ternak dihadapkan pada suatu perubahan suhu lingkungan panas. Respon awalnya adalah menurunnya nafsu makan dan tingginya konsumsi air minum. Farrel (1979) menyatakan heat stres berpengaruh nyata terhadap fisiologis ayam, terutama setelah ayam berumur lebih dari 3 minggu, karena pada umur tersebut bulu penutup tubuh sudah lengkap. Faktor lingkungan (cekaman panas) ini dapat menimbulkan kerugian yang diakibatkan adanya cekaman suhu panas seperti penurunan bobot badan, peningkatan rasio konversi pakan dan adanya angka kematian (Kuczynski, 2002; Gunawan dan Sihombing, 2004). Lebih lanjut dijelaskan oleh Kuczynski (2002) pada anak ayam umur 1 - 2 minggu diperlukan suhu lingkungan yang relatif tinggi, sedangkan umur $4-6$ 
minggu, ayam memerlukan suhu lingkungan relatif rendah. Ayam umur $4-6$ minggu memerlukan suhu lingkungan rendah disebabkan karena ayam broiler tidak memiliki kelenjar keringat ditambah lagi dengan keberadaan bulu yang hampir menutupi seluruh bahagian tubuh ayam. Tidak adanya kelenjar keringat dan keberadaan bulu yang menutupi hampir seluruh tubuh akan mengakibatkan terhambatnya proses pembuangan panas baik yang berasal dari metabolisme tubuh maupun yang berasal dari lingkungan. Untuk mendapatkan pertumbuhan yang optimal harus ada keseimbangan antara pembentukan panas dan pengeluaran panas dari tubuh. Terjadinya cekaman panas akibat ketidakseimbangan antara jumlah panas yang dihasilkan tubuh dengan jumlah panas yang dilepaskan tubuh ke lingkungan (Lin et al., 2006).

Untuk mendapatkan pertumbuhan optimum pada anak ayam pedaging umur di atas 20 hari diperlukan suhu lingkungan antara $20-25^{\circ} \mathrm{C}$ dan kelembaban antara $50-70 \%$ (Borges et al., 2004), sedangkan ayam broiler umur di atas 3 minggu yang mendapat suhu lingkungan di atas $32^{\circ} \mathrm{C}$ akan mengalami cekaman panas yang serius (Cooper dan Washburn, 1998). Jika suhu lingkungan tinggi akan memberikan dampak negatif terhadap kondisi fisiologis dan produktivitas ayam broiler. Ciri-ciri seekor ayam yang mengalami stres panas ditandai dengan adanya kegelisahan dalam kandang, mengembangkan sayap dan panting, juga terjadi penurunan konsumsi pakan. Turunnya konsumsi pakan menyebabkan terjadinya penurunan pertumbuhan.

Suhu lingkungan yang tinggi juga berpengaruh terhadap peningkatan aktivitas metabolisme basal, juga terhadap aktivitas hormonal. Fuller dan Rendom (1977), menyatakan suhu lingkungan tinggi berpengaruh langsung terhadap peningkatan aktivitas organ tubuh seperti jantung, pernafasan dan sirkulasi darah feriver, dan pengaruh secara tidak langsung dapat meningkatkan hormon kortisol, kortikosteron serta menurunnya hormon tiroksin dan adrenalin dalam darah.
Disinyalir bahwa vitamin $\mathrm{C}$ dapat menetralisir pengaruh cekaman panas. Vitamin C secara fisiologi berperan terhadap aktivitas kelenjar tiroid, karena vitamin $\mathrm{C}$ sebagai kosubstrat dari dopamin $\beta$ hidroksilase dalam pembentukan Norepinefrin sehingga kemampuan ayam untuk membuang panas melalui mekanisme memacu denyut jantung dan dilatasi pembuluh perifer dapat ditingkatkan yang mengakibatkan suhu tubuh ayam jadi rendah. (Mitzler, 1977).

Pada ayam yang menderita cekaman panas melepaskan berbagai jenis senyawa biokimia, seperti beberapa jenis hormon glukokortiroid dan sitokin. Sitokin yang dilepaskan memegang peran penting dalam upaya tubuh mempertahankan homeostasis akibat stress (Huang et al., 2003). Penelitian penanganan stres (cekaman panas) pada ayam broiler telah banyak dilaporkan. Penggunaan vitamin dilaporkan dapat mengurangi dampak cekaman panas (Borges et al., 2004; AlSultan, 2003).

Tanaman mengkudu merupakan tanaman yang dapat tumbuh dengan mudah di daerah tropis seperti Indonesia dan Malaysia (Heinecke, 2003; Chan-Blanco et al., 2006 dan Mohd Zin et al., 2002). Mengkudu salah satu tanaman obat yang cukup potensial untuk dikembangkan karena mengandung beberapa zat yang berguna antara lain: antioksidan, alkaloid, antrakinon, flavonoid, tanin, saponin dan vitamin C (Syamsuhidayat dan Hutapea, 1991; Chong et al., 2005; Chiang dan Abdullah, 2007). Sehubungan dengan hal tersebut buah mengkudu (Morinda citrifolia Linn), mengandung antioksidan yang cukup tinggi yaitu $324,70 \mathrm{mg} / 100 \mathrm{~g}$ dalam sari buah mengkudu (hasil analisis lab. Uji Teknologi Pangan dan Hasil Pertanian, Fakultas Pertanian UGM, 2010). Antioksidan adalah inhibitor yang bekerja menghambat oksidasi dengan cara bereaksi dengan radikal bebas reaktif membentuk radikal bebas tak reaktif yang relatif stabil atau senyawa yang melindungi sel dari efek berbahaya radikal bebas oksigen reaktif (Laguerre et al., 2007; Matkowski et al., 2006; Rao et al., 2007; Montoro et al., 2005). Menurut (Kadam et al., 2008; Deng et al., 2007), antioksidan alami 
yang terdapat dalam bahan pangan dapat dikategorikan menjadi golongan zat gizi yang terdiri dari vitamin C, vitamin E dan B Karoten. Potensi mengkudu pada tahun 2008 di Indonesia, sekitar $725.813 \mathrm{Ha}$ dengan produksi 3.509.087 Ton (BPS, 2009).

Beberapa penelitian dapat membuktikan bahwa pemberian antioksidan yang mengandung vitamin $\mathrm{C}$ dapat mengurangi dampak cekaman panas pada ayam. Hal ini berkaitan dengan berkurangnya pembentukan vitamin $\mathrm{C}$ akibat gangguan pada organ tubuh penghasil vitamin $C$ tersebut sehingga untuk memenuhi kebutuhannya perlu ditambahkan dari luar. Pemberian vitamin C $800 \mathrm{mg} / \mathrm{kg}$ pakan dapat meningkatkan imunitas humoral pada ayam broiler yang diberi cekaman panas (Angwanich et al., 2003).

Dari uraian di atas dilakukan penelitian dengan tujuan pemberian antioksidan dalam buah mengkudu diharapkan dapat menetralisir efek cekaman panas bagi ayam yang dipelihara di daerah tropis tanpa mempengaruhi performannya.

\section{METODE}

Penelitian dilakukan di UPT Fakultas Peternakan Unand Limau Manis Padang, Sumatera Barat, penelitian dilakukan untuk menguji efek antioksidan dengan level $(0$, 500, 1000 dan $1500 \mathrm{ppm}$ ) dalam sari buah mengkudu terhadap respon ayam pedaging pada tiga macam suhu ruangan dengan memakai $\mathrm{AC}$, fan dan alat pemanas ruangan masing-masing $20^{\circ} \mathrm{C}, 26^{\circ} \mathrm{C}$ dan $32^{\circ} \mathrm{C}$. Materi penelitian : 360 ekor broiler umur dua minggu strain Arbor Acress. Penelitian selama 8 minggu (dari tanggal 18 Juni 2010 s/d 13 Agustus 2010). Rancangan percobaan RAL model Split plot $(3 \times 4)$ dengan 3 ulangan, masing-masing 10 ekor ayam untuk setiap box, main plot (Suhu ruangan $20^{\circ} \mathrm{C}, 26^{\circ} \mathrm{C}$ dan $32^{\circ} \mathrm{C}$ ) serta sub plot (pemberian antioksidan dalam sari buah mengkudu melalui air minum 0 ppm, 500 ppm, 1000 ppm dan 1500 ppm). Ransum disusun iso protein dan iso energi dengan PK 22\% dan EM $3000 \mathrm{kkal} / \mathrm{kg}$. Beberapa parameter produksi dan fisiologis yang dianggap sangat berperan dalam proses homeostasis adalah konsumsi pakan, konversi pakan, kadar tiroksin dan bobot bursa fabrisius. Data yang diperoleh dianalisis secara statistik dengan menggunakan program paket SAS (1998) dan jika menunjuk kan pengaruh yang nyata dilanjutkan dengan Uji Duncan Multiple Range Test/ DMRT Steel dan Torrie (2005).

\section{Peubah yang diukur}

1. Konsumsi pakan, dinyatakan dalam g/ekor/minggu. Jumlah pakan yang disediakan setiap minggu untuk masingmasing perlakuan ditempatkan dalam kantong plastik, bobot awalnya ditimbang dan dicatat, demikian juga jumlah sisa makanan dalam kantung plastik dan bak makanan pada akhir minggu bersangkutan ditimbang dan dicatat. Selisih berat awal minggu dan akhir minggu merupakan jumlah makanan yang dikonsumsi pada minggu yang sama.

2. Konversi pakan, diamati pada umur 8 minggu dengan membagi konsumsi pakan dengan pertambahan bobot badan.

3. Kadar hormon tiroksin, dianalisis dengan teknik Radioimmunoassay. Kit hormone beserta prosedur penggunaannya diperoleh dari Diagnostic Products Corporation, Los Angeles.

4. Bobot bursa fabrisius, dinyatakan dalam $\mathrm{mg} / 100 \mathrm{~g}$ bobot hidup sebelum dipotong. Bursa fabrisius dikeluarkan dan ditimbang

\section{HASIL DAN PEMBAHASAN}

\section{Kondisi iklim mikro ruang penelitian}

Rataan suhu harian dalam ruangan penelitian selama penelitian berlangsung disajikan pada Tabe1 1.

Tabel 1. Rataan Suhu Ruangan Penelitian Selama Penelitian Berlangsung

\begin{tabular}{ccc}
\hline & \multicolumn{2}{c}{ Suhu ruangan $\left({ }^{\circ} \mathrm{C}\right)$} \\
\cline { 2 - 3 } Ruangan & Rataan & Kisaran \\
\hline $\mathrm{R}_{1}$ & 20 & $19-21$ \\
$\mathrm{R}_{2}$ & 26 & $25-27$ \\
$\mathrm{R}_{3}$ & 32 & $31-33$ \\
\hline
\end{tabular}


Perbedaan suhu untuk masing-masing ruangan cukup menyolok ditinjau dari zona suhu lingkungan yang mempengaruhi ternak. $\mathrm{R}_{1}$ dengan rataan suhu $20^{\circ} \mathrm{C}$ merupakan suhu lingkungan yang berada di dalam kisaran thermonetral untuk broiler yakni antara 18 $22^{\circ} \mathrm{C}$ (Charles, 2002). Ruangan $\mathrm{R}_{2}$ dengan rataan suhu $26^{\circ} \mathrm{C}$ merupakan rataan suhu ruangan yang berada di sekitar batas atas suhu kenyamanan dan suhu ini umumnya terjadi di daerah pegunungan di wilayah Sumatera Barat.

Ruangan $\mathrm{R} 3$ dengan rataan suhu $32^{\circ} \mathrm{C}$ merupakan suhu ruangan yang berada di dalam kisaran suhu tinggi. Berdasarkan suhu nyaman yang dinyatakan oleh Charles (2002) yaitu $18-22^{0} \mathrm{C}$, maka broiler yang dipelihara pada suhu $32^{\circ} \mathrm{C}$ akan mengalami cekaman panas yang ditandai dengan menurunnya konsumsi makanan, tingkat pertumbuhan, dan terjadinya gangguan fisiologis.

\section{Pengaruh Perlakuan Terhadap Konsumsi Pakan}

Pengaruh suhu ruangan dan pemberian antioksidan yang mengandung vitamin $\mathrm{C}$ dalam sari buah mengkudu terhadap rata-rata konsumsi pakan ayam broiler umur 8 minggu, disarikan dalam Tabel 2. Dari Tabel 2 terlihat bahwa terdapat interaksi antara suhu lingkungan dengan pemberian antioksidan yang mengandung vitamin $\mathrm{C}$ dalam sari buah mengkudu yang memberikan pengaruh berbeda sangat nyata $(\mathrm{P}<0,01)$ terhadap konsumsi pakan. Ayam broiler yang dipelihara pada suhu $20^{\circ} \mathrm{C}$ pemberian antioksidan $500 \mathrm{ppm}$,
$1.000 \mathrm{ppm}$ dan $1.500 \mathrm{ppm}$ dalam sari buah mengkudu melalui air minum tidak berpengaruh terhadap konsumsi pakan, tetapi pada ayam yang dipelihara pada temperatur $26^{\circ} \mathrm{C}$ pemberian antioksidan $500 \mathrm{ppm}$ dalam sari buah mengkudu dapat meningkatkan konsumsi pakan dari 4.990,079 g /ekor menjadi $5.228,676 \mathrm{~g} /$ ekor dan sama dengan konsumsi ayam yang dipelihara pada temperatur netral, tetapi pada ayam yang dipelihara pada suhu $32^{\circ} \mathrm{C}$ pemberian antioksidan $1000 \mathrm{ppm}$ dalam sari buah mengkudu terjadi peningkatan konsumsi dari 4.483,833 g/ ekor menjadi $5.219,543 \mathrm{~g} /$ ekor dan jumlah konsumsi ini secara statistik tidak berbeda dengan konsumsi ayam yang dipelihara pada temperatur netral.

Meningkatnya konsumsi pakan dari ayam yang dipelihara pada suhu $26^{\circ} \mathrm{C}$ dengan pemberian antioksidan $500 \mathrm{ppm}$ dan 1.000 ppm sari buah mengkudu dalam air minum pada ayam yang pelihara pada suhu $32^{\circ} \mathrm{C}$, disebabkan pada level 500 ppm pada temperatur $26^{\circ} \mathrm{C}$ dan $1.000 \mathrm{ppm}$ pada temperatur $32^{\circ} \mathrm{C}$ dapat melindungi bursa fabrisius dari cekaman panas sehingga dengan pemberian antioksidan yang mengandung vitamin $\mathrm{C}$ pada level tersebut dapat meningkatkan konsumsi pakan yang dapat menyamai konsumsi pakan ayam broiler yang dipelihara pada temperatur netral. Kondisi ini sesuai dengan pernyataan Aengwanich et al. (2003) bahwa pemberian vitamin $C$ sebanyak $800 \mathrm{mg} / \mathrm{kg}$ ransum dapat memberikan kekebalan hormonal tertinggi, di bawah cekaman panas sehingga berdampak positif pada kesehatan dan konsumsi ternak.

Tabel 2. Rataan Konsumsi Pakan Selama Penelitian (g/ekor)

\begin{tabular}{cccccc}
\hline \multirow{2}{*}{$\begin{array}{c}\text { Suhu Ruangan }\left({ }^{\circ} \mathrm{C}\right) / \text { main } \\
\text { plot }\end{array}$} & \multicolumn{4}{c}{ Antioksidan (ppm)/ sub plot } & \multirow{2}{*}{ Rataan } \\
\cline { 2 - 5 } & 0 & 500 & 1.000 & 1.500 & \\
\hline 20 & $5.249,369^{\mathrm{Aa}}$ & $5.202,653^{\mathrm{Aa}}$ & $5.217,686^{\mathrm{Aa}}$ & $5.201,326^{\mathrm{Aa}}$ & $5.217,759$ \\
26 & $4.990,079^{\mathrm{Bb}}$ & $5.228,676^{\mathrm{Aa}}$ & $5.199,413^{\mathrm{Aa}}$ & $5.202,766^{\mathrm{Aa}}$ & $5.155,234$ \\
32 & $4.483,833^{\mathrm{Cc}}$ & $5.040,303^{\mathrm{Bb}}$ & $5.219,543^{\mathrm{Aa}}$ & $5.243,449^{\mathrm{Aa}}$ & $4.996,782$ \\
\hline Rataan & $4.907,761$ & $5.157,211$ & $5.212,214$ & $5.215,847$ & \\
\hline
\end{tabular}

Keterangan : Superskrip yang berbeda menurut kolom (A, B) dan baris (a, b) menunjukkan pengaruh berbeda sangat nyata $(\mathrm{P}<0,01)$. 
Pada Tabel 2 dapat dilihat semakin tinggi suhu lingkungan semakin turun konsumsi pakan. Konsumsi pakan ayam yang dipelihara pada suhu $32^{\circ} \mathrm{C}$ sebanyak $4.483,833$ g/ekor secara statistik lebih rendah $(\mathrm{P}<0,05)$ dari konsumsi ayam yang dipelihara pada temperatur $26^{\circ} \mathrm{C}$ dan $20^{\circ} \mathrm{C}$ masing-masingnya $4.990,079$ g/ekor dan 5.249,369 g/ekor. Turunnya konsumsi pakan ayam pada temperatur lingkungan tinggi mengakibatkan rendahnya pertambahan bobot badan. Hal ini dapat dijelaskan bahwa suhu lingkungan tinggi berpengaruh terhadap turunnya konsumsi pakan dan naiknya konsumsi air minum, mengakibatkan menurunnya laju pertambahan bobot badan, serta menaikkan suhu tubuh dan laju pernafasan (Fuller dan Rendom, 1977; Abu-Dyeh, 2006). Lebih lanjut dijelaskan bahwa peningkatan fungsi organ-organ tubuh dan alat pernafasan merupakan gambaran dari aktivitas metabolisme basal pada suhu lingkungan tinggi jadi meningkat. Meningkatnya laju metabolisme basal disebabkan bertambahnya penggunaan energi sebagai akibat bertambahnya frekuensi pernafasan, kerja jantung dan meningkatnya sirkulasi darah perifer. Melihat dampak dari temperatur di atas thermoneutral akan mengakibatkan kebutuhan energi lebih tinggi sehingga energi yang seharusnya dapat didepositkan menjadi daging (pertambahan bobot badan) digunakan untuk mempertahankan suhu tubuh. Rendahnya konsumsi pakan dan menurunnya laju pertumbuhan berkaitan erat dengan sekresi hormon kortisol dan tiroksin.
Pada suhu lingkungan tinggi, sekresi hormon kortisol meningkat dan tiroksin menurun, hal ini menyebabkan meningkatnya katabolisme dan menurunkan anabolisme. Pada penelitian ini terlihat kadar tiroksin dalam plasma darah broiler yang berada pada suhu lingkungan $32^{\circ} \mathrm{C}$ lebih rendah dibanding dengan broiler yang berada pada suhu lingkungan $26^{\circ} \mathrm{C}$ dan $20^{\circ} \mathrm{C}$ yaitu $0,366 \mu \mathrm{g} / \mathrm{dl}$; $0,596 \mu \mathrm{g} / \mathrm{dl}$ dan $0,916 \mu \mathrm{g} / \mathrm{dl}$. Hasil penelitian ini sama dengan hasil penelitian Kusnadi et al. (2006) bahwa pemberian vitamin C dapat meningkatkan konsumsi pakan dan pertambahan bobot badan ayam broiler yang mengalami cekaman panas.

Yi et al. (2009) menyatakan hormon tiroid merupakan hormon yang sangat berperan dalam pertumbuhan, melalui peningkatan konsumsi oksigen yang penting untuk metabolisme secara umum. Sintesis dan sekresi hormon tiroid sangat dipengaruhi oleh suhu lingkungan tinggi.

\section{Pengaruh Perlakuan Terhadap Konversi Pakan}

Pengaruh suhu ruangan dan pemberian antioksidan yang mengandung vitamin $\mathrm{C}$ dalam sari buah mengkudu terhadap rata-rata konversi pakan ayam broiler umur 8 minggu, disarikan dalam Tabel 3. Dari Tabel 3 dapat dilihat bahwa ada interaksi antara suhu lingkungan dengan pemberian antioksidan yang mengandung vitamin $\mathrm{C}$ dalam sari buah mengkudu yang memberikan pengaruh berbeda sangat nyata $(\mathrm{P}<0,01)$ terhadap rasio konversi pakan.

Tabel 3. Rataan Konversi Pakan Selama Penelitian.

\begin{tabular}{cccccc}
\hline Suhu Ruangan $\left({ }^{\circ} \mathrm{C}\right) /$ main plot & \multicolumn{3}{c}{ Antioksidan $(\mathrm{ppm}) / \mathrm{sub}$ plot } & \multirow{2}{*}{ Rataan } \\
\cline { 2 - 5 } & 0 & 500 & 1000 & 1500 & \\
\hline 20 & $2,026^{\mathrm{Aa}}$ & $2,016^{\mathrm{Aa}}$ & $2,016^{\mathrm{Aa}}$ & $2,006^{\mathrm{Aa}}$ & 2,016 \\
26 & $2,466^{\mathrm{Bb}}$ & $2,026^{\mathrm{Aa}}$ & $2,016^{\mathrm{Aa}}$ & $2,016^{\mathrm{Aa}}$ & 2,131 \\
32 & $3,216^{\mathrm{Cc}}$ & $2,446^{\mathrm{Bb}}$ & $2,026^{\mathrm{Aa}}$ & $2,026^{\mathrm{Aa}}$ & 2,428 \\
\hline Rataan & 2,569 & 2,162 & 2,019 & 2,016 & \\
\hline
\end{tabular}

Keterangan : Superskrip yang berbeda menurut kolom (A, B) dan baris (a, b) menunjukkan pengaruh berbeda sangat nyata $(\mathrm{P}<0,01)$. 
Ayam broiler yang dipelihara pada temperatur lingkungan $26^{\circ} \mathrm{C}$ tanpa diberikan antioksidan menghasilkan rasio konversi pakan 2,466 dan dengan pemberian $500 \mathrm{ppm}$ antioksidan dalam sari buah mengkudu dapat menurunkan rasio konversi pakan menjadi 2,026. Sedangkan rasio konversi pakan pada ayam yang dipelihara pada temperatur $32^{\circ} \mathrm{C}$ menghasilkan rasio konversi pakan 3,216 dan dengan penambahan antioksidan dalam sari buah mengkudu 1.000 ppm menjadi 2,026. Turunnya rasio konversi pakan dengan pemberian antioksidan $1.000 \mathrm{ppm}$ disebabkan karena konsumsi pakan maupun pertambahan bobot badan juga meningkat dengan pemberian $1.000 \mathrm{ppm}$ antioksidan dalam sari buah mengkudu. Rasio konversi pakan merupakan hasil perbandingan antara konsumsi pakan dengan pertambahan bobot badan.

Disini terlihat semakin tinggi temperatur semakin besar rasio konversi pakan. Tingginya rasio konversi pakan $(\mathrm{P}<0,05)$ pada temperatur $32^{\circ} \mathrm{C}$ yaitu 3,216 dibanding temperatur $20^{\circ} \mathrm{C}$ dan $26^{\circ} \mathrm{C}$ yaitu 2,026 dan 2,466 disebabkan lebih banyaknya energi yang digunakan untuk pemeliharaan suhu tubuh yang mengakibatkan lebih sedikitnya energi yang tersedia untuk pertumbuhan, sedangkan Fuller dan Rendom, (1977) menyatakan bahwa meningkatnya laju metabolisme basal akan menyebabkan penggunaan energi sebagai akibat bertambahnya frekuensi pernafasan, kerja jantung dan bertambahnya sirkulasi darah perifer dengan naiknya kebutuhan energi di atas temperatur netral akan lebih tinggi. Austic (2000) menyatakan kemungkinan energi yang dikonsumsi lebih banyak digunakan untuk mempertahankan keseimbangan suhu tubuh ayam saat ayam menerima cekaman panas. Lin et al. (2006) menyatakan pada suhu lingkungan panas terdapat suatu hubungan yang tidak langsung antara pertambahan bobot badan dengan energi yang dikeluarkan. Siegel (1995) menyatakan dalam proses adaptasi dalam lingkungan heat stres terdapat hubungan yang erat antara konsumsi pakan dengan pemborosan energi yang terbuang. Hal ini sesuai dengan pernyataan Quinteiro-Filho et al. (2010) menyatakan heat stres akan menyebabkan terjadinya penurunan bobot badan dan konsumsi pakan serta terjadinya peningkatan rasio konversi pakan.

Rasio konsumsi pakan antara temperatur $20^{\circ} \mathrm{C}$ yaitu 2,026 dengan $26^{\circ} \mathrm{C}$ yaitu 2,466 terdapat perbedaan secara nyata terhadap peningkatan rasio konversi pakan. Hal ini kemungkinan ada perbedaan kebutuhan energi untuk mempertahankan keseimbangan suhu tubuh dengan temperatur lingkungan, dimana semakin tinggi suhu lingkungan semakin besar energi yang digunakan tubuh ayam untuk menetralisir panas tubuh. Pada ayam yang mengalami cekaman panas jalur utama untuk menjaga keseimbangan suhu adalah dengan pelepasan panas tubuh melalui saluran pernafasan dengan cara panting dan juga melalui penguapan air dipermukaan kulit (Hoffman dan Walsberg, 1999).

Penguapan air melalui peningkatan pengaturan aliran darah dengan cara pelebaran pembuluh perifer (vasodilatasi) sehingga pembuluh darah lebih banyak membawa darah dari dalam (Core) ke permukaan tubuh. Vasodilatasi pembuluh darah tepi ini sangat berperan pada evaporasi penguapan dalam upaya pelepasan panas dari tubuh (Cooper dan Wasburn, 1998). Panting dan vasodilatasi membutuhkan energi sehingga pada temperatur $32^{\circ} \mathrm{C}$ konversi pakan tertinggi dan pertambahan bobot badan yang rendah, dimana energi yang dikonsumsi digunakan untuk mempertahankan keseimbangan suhu tubuh dengan temperatur lingkungan yang mengakibatkan pertambahan bobot badan pada temperatur $32^{\circ} \mathrm{C}$ jadi rendah.

Hal ini sesuai dengan pernyataan Puthpongsiriporn et al. (2001) yang menyatakan bahwa vitamin $\mathrm{C}$ telah dibuktikan dapat digunakan dengan baik untuk mengatasi cekaman panas dengan demikian konsumsi pakan maupun pertambahan bobot badan tidak terganggu sehingga rasio konversi pakan pun sama dengan rasio konversi pada ayam yang dipelihara pada temperatur netral.

\section{Pengaruh Perlakuan Terhadap Kadar Tiroksin}

Pengaruh suhu ruangan dan pemberian antioksidan yang mengandung vitamin $\mathrm{C}$ dalam sari buah mengkudu terhadap rata-rata 
kadar tiroksin plasma darah ayam broiler umur 8 minggu, disarikan dalam Tabel 4.

Terdapat interaksi antara pemberian antioksidan yang mengandung vitamin $\mathrm{C}$ dalam sari buah mengkudu dengan temperatur lingkungan yang memberikan pengaruh berbeda sangat nyata $(\mathrm{P}<0,01)$ terhadap kadar tiroksin dalam plasma darah. Pada temperatur $20^{\circ} \mathrm{C}$ pemberian antioksidan dalam sari buah mengkudu dalam air minum tidak berpengaruh terhadap kadar tiroksin plasma darah, tetapi pada temperatur $26^{\circ} \mathrm{C}$ dapat meningkatkan kadar tiroksin dari $0,596 \mu \mathrm{g} / \mathrm{dl}$ menjadi $0,916 \mu \mathrm{g} / \mathrm{dl}$ dan pada temperatur $32^{\circ} \mathrm{C}$ $0,366 \mu \mathrm{g} / \mathrm{dl}$ menjadi $0,806 \mu \mathrm{g} / \mathrm{dl}$.

Pemberian antioksidan $500 \mathrm{ppm}$ dalam sari buah mengkudu pada ayam yang dipelihara dengan suhu $26^{\circ} \mathrm{C}$ dapat meningkatkan dan menyamai kandungan tiroksin pada ayam yang dipelihara pada temperatur netral. Sedangkan pada ayam yang dipelihara pada suhu $32^{\circ} \mathrm{C}$ pemberian antioksidan sari buah mengkudu 1.000 ppm dapat memberikan hasil yang sama dengan kadar tiroksin pada ayam broiler yang dipelihara pada temperatur netral. Aktivitas kalenjar tiroid dipengaruhi oleh kondisi lingkungan, pada ayam yang mengalami cekaman panas aktivitas kelenjar tiroid mengalami penurunan (Sahin et al., 2001; Gyorffy et al., 2009) dan akan mempengaruhi sekresi hormon yang dihasilkannya.

Berdasarkan hasil penelitian seperti terlihat pada Tabel 4 ternyata bahwa semakin tinggi suhu ruangan semakin rendah kadar tiroksin pada plasma darah. Kadar hormon tiroksin pada ayam yang dipelihara pada suhu $20^{\circ} \mathrm{C}$ yaitu $0,916 \mu \mathrm{g} / \mathrm{dl}$ lebih tinggi diban- dingkan dengan ayam yang dipelihara pada suhu 26 dan $32^{\circ} \mathrm{C}$ yaitu $0,596 \mu \mathrm{g} / \mathrm{dl}$ dan 0,366 $\mu \mathrm{g} / \mathrm{dl}$. Hal ini sesuai dengan penyataan Sahin et al. (2001) terjadi penurunan konsentrasi hormon T3 (Triiodotironin) dalam sirkulasi darah. Lebih lanjut Decuypere et al. (2005) dan Downing dan Bryden, (2002) menyatakan bahwa hormon tiroksin dihasilkan oleh kelenjar tiroid dan Ringer (1976) menyatakan terdapat hubungan antara musim dengan aktivitas kelenjar tiroid, pada musim panas aktivitas kelenjar tiroid rendah dibanding pada musim dingin. Sedangkan kadar tiroksin berbanding terbalik dengan suhu lingkungan semakin tinggi suhu lingkungan kadar tiroksin dalam plasma darah semakin rendah. Rendahnya sekresi hormon tiroksin pada suhu lingkungan tinggi merupakan faktor penting penyebab turunnya konsumsi pakan. Hormon triiodotironin (T3) dan tiroksin (T4) mempunyai peranan penting untuk meningkatkan pertumbuhan dan metabolisme energi. Rendahnya kadar tiroksin pada ayam yang mengalami cekaman panas maupun pada ayam yang diperlakukan dengan pembatasan makanan, erat kaitannya dengan turunnya konsumsi oksigen dan metabolisme secara umum (Geraert et al., 1996; Decuypere et al., 2005; Navidshad et a.l, 2006).

Menurunnya aktivitas kelenjar tiroid akibat cekaman panas dilaporkan oleh Kusnadi (2009), bahwa terjadi penurunan kandungan hormon $\mathrm{T} 3$ dalam plasma secara nyata dari $1,71 \pm 0,62$ pada ayam yang dipelihara pada suhu $28,55 \pm 1,53^{\circ} \mathrm{C}$ menjadi $0,62 \pm 0,35$ dan $0,64 \pm 0,23$ ayam yang

Tabel 4. Rataan Kadar Tiroksin Plasma Darah Broiler umur 8 Minggu $(\mu g / d l)$.

\begin{tabular}{cccccc}
\hline \multirow{2}{*}{$\begin{array}{c}\text { Suhu Ruangan }\left({ }^{\circ} \mathrm{C}\right) / \text { main } \\
\text { plot }\end{array}$} & \multicolumn{3}{c}{ Antioksidan $(\mathrm{ppm}) /$ sub plot } & \multirow{2}{*}{ Rataan } \\
\cline { 2 - 4 } & 0 & 500 & 1000 & 1500 & \\
\hline 20 & $0,916^{\mathrm{Aa}}$ & $0,946^{\mathrm{Aa}}$ & $0,926^{\mathrm{Aa}}$ & $0,936^{\mathrm{Aa}}$ & 0,936 \\
26 & $0,596^{\mathrm{Bb}}$ & $0,916^{\mathrm{Aa}}$ & $0,916^{\mathrm{Aa}}$ & $0,926^{\mathrm{Aa}}$ & 0,836 \\
32 & $0,366^{\mathrm{Cc}}$ & $0,806^{\mathrm{Ab}}$ & $0,926^{\mathrm{Aa}}$ & $0,936^{\mathrm{Aa}}$ & 0,754 \\
\hline Rataan & 0,626 & 0,889 & 0,923 & 0,933 & \\
\hline
\end{tabular}

Keterangan : Superskrip yang berbeda menurut kolom (A, B) dan baris (a, b) menunjukkan pengaruh berbeda sangat nyata $(\mathrm{P}<0,01)$. 
dipelihara pada suhu $31,07 \pm 1,29^{\circ} \mathrm{C}$ dan $33,50 \pm 1,17^{\circ} \mathrm{C}$ serta diiringi dengan penurunan bobot badan dari $1014 \pm 85$ menjadi $829 \pm 87$ dan $664 \pm 93 \mathrm{~g}$ pada umur 6 minggu. Turunnya kadar tiroksin dalam darah akibat cekaman panas dijelaskan oleh Rastogi (1984) panas suhu tubuh yang dikontrol oleh hypothalamus dimana bagian anterior hypothalamus sebagai pusat pelepasan panas dan bagian posterior sebagai pusat produksi panas. Permukaan kulit sebagai reseptor penerima panas akan meneruskan ke hypothalamus bagian anterior. Hypothalamus anterior akan merespon umpan balik untuk mengatasi cekaman panas dengan memacu peningkatan frekuensi denyut jantung. Hypothalamus akan menggertak peningkatan penguapan keringat melalui kulit dengan jalan memperbesar pembuluh darah kapiler bagian permukaan.

Cekaman panas yang berlangsung berkepanjangan, untuk menetralisir cekaman panas tidak dapat lagi di atasi dengan peningkatan denyut jantung, penguapan panas melalui kulit dan pernafasan maka diperlukan pengaturan metabolisme. Rangsangan panas yang diterima oleh hypotalamus menyebabkan hypothalamus mengurangi/menekan produksi TRF, dengan sendirinya rangsangan ke hypofisa anterior untuk mensekresikan TSH jadi berkurang, akibatnya aktivitas kelenjar tiroid untuk memproduksi tiroksin jadi berkurang sehingga kadar tiroksin dalam darah menjadi rendah.

Pemberian antioksidan yang mengandung vitamin $\mathrm{C}$ dalam sari buah mengkudu memberikan pengaruh nyata terhadap kadar tiroksin dalam plasma darah ayam broiler umur 8 minggu. Pada ayam yang dipelihara pada suhu $20^{\circ} \mathrm{C}$ pemberian antioksidan yang mengandung vitamin $\mathrm{C}$ dalam sari buah mengkudu 500 ppm tidak berpengaruh terhadap kadar tiroksin dalam plasma darah sedangkan ayam yang dipelihara pada suhu $26^{\circ} \mathrm{C}$ dan $32^{\circ} \mathrm{C}$ pemberian antioksidan yang mengandung vitamin $\mathrm{C}$ dalam sari buah mengkudu sebanyak 500 ppm dapat meningkatkan kadar tiroksin dalam plasma darah secara nyata dari $0,596 \mu \mathrm{g} / \mathrm{dl}$ dan $0,366 \mu \mathrm{g} / \mathrm{dl}$ menjadi $0,916 \mu \mathrm{g} / \mathrm{dl}$ dan $0,806 \mu \mathrm{g} / \mathrm{dl}$. Hal yang sama dilaporkan oleh Kusnadi et al., (2006), bahwa pemberian vitamin C sebanyak 500 ppm dapat meningkatkan hormon T3 dalam darah dari $115 \mu \mathrm{g} / \mathrm{dl}$ menjadi $136 \mu \mathrm{g} / \mathrm{dl}$ pada ayam yang dipelihara pada suhu 31,98 \pm $1,28^{\circ} \mathrm{C}$ dan diiringi dengan kenaikan bobot badan secara nyata dari $1.181 \pm 66 \mathrm{~g}$ menjadi $1.254 \pm 35 \mathrm{~g}$ dengan konversi pakan yang sama. Pemberian antioksidan yang mengandung vitamin $\mathrm{C}$ dapat mengaktivasi kelenjar tiroid untuk meningkatkan sekresi tiroksin karena sesuai dengan pernyataan Christensen (1983); Hornig dan Frigg (1979) bahwa, pada kondisi lingkungan normal biosintesis vitamin $\mathrm{C}$ pada ternak secara umum terdapat dalam jumlah yang cukup untuk memenuhi kebutuhan fisiologisnya, tetapi pada kondisi lingkungan temperatur tinggi sintesis vitamin $C$ tidak lagi mencukupi sedangkan Mitzler (1977) menyatakan bahwa, vitamin $\mathrm{C}$ secara fisiologis berpengaruh terhadap aktivitas tiroid dimana vitamin $\mathrm{C}$ sebagai kosubstrat dari dopamin $\beta$ hidroksilase dalam pembentukan norepineprin sehingga kemampuan ayam untuk membuang panas dengan memacu denyut jantung dan dilatasi pembuluh darah perifer dapat ditingkatkan. Pada kondisi lingkungan normal biosintesis vitamin $\mathrm{C}$ pada ternak secara umum terdapat dalam jumlah yang cukup untuk memenuhi kebutuhan fisiologisnya, tetapi pada kondisi lingkungan temperatur tinggi sintesis vitamin $\mathrm{C}$ tidak lagi mencukupi (Christensen, 1983; Hornig et al., 1983).

Apabila cekaman panas berlangsung terus dan cekaman panas tidak dapat lagi di atasi dengan peningkatan denyut jantung dan penguapan melalui kulit, maka diperlukan pengaturan metabolisme yaitu rangsangan yang diterima oleh hypothalamus menyebabkan hypothalamus mengurangi/menekan produksi TRF (Tiroid Realising Factor), tak berarti rangsangan ke hypofisa anterior untuk mensekresikan TSH jadi berkurang. Akibatnya aktivitas kelenjar tiroid untuk menghasilkan tiroksin jadi berkurang sehingga kadar tiroksin dalam plasma darah jadi rendah Penambahan antioksidan yang mengandung vitamin $\mathrm{C}$ dalam sari buah mengkudu 500 
ppm pada ayam yang dipelihara pada suhu lingkungan tinggi (temperatur $26^{\circ} \mathrm{C}$ dan $32^{\circ} \mathrm{C}$ ) dapat meningkatkan hormon tiroksin, karena vitamin $\mathrm{C}$ memiliki gugus hidroksil yang mudah teroksidasi sehingga dengan mudah mampu mendonorkan elektron dan hidrogen terhadap radikal bebas (Sediaoetama, 1987). Akibatnya radikal bebas yang semula memiliki elektron yang tidak berpasangan menjadi stabil. Lebih lanjut dijelaskan oleh Ichsan (1991) bahwa, peran vitamin C dalam aktivitas tiroid mungkin terkait dengan fungsi vitamin $\mathrm{C}$ sebagai transpor elektron, sehingga dapat memberikan elektron dalam reaksi penggabungan dengan iodium dalam pembentukan tiroksin, hal ini dapat menaikkan kadar tiroksin dalam plasma darah. Sesuai dengan fungsi hormon tiroksin yang dihasilkan kelenjar tiroid memegang peranan penting dalam mempercepat pertumbuhan dan metabolisme energi (Sahin et al., 2001). Kusnadi et al. (2006) menyatakan, bahwa antanan dan vitamin $\mathrm{C}$ berperan baik sebagai antioksidan, sehingga mampu mengatasi turunnya konsumsi ransum dan pertambahan bobot badan pada kondisi cekaman panas. (Schemiling dan Nockels, 1978) kenaikan berat badan yang terjadi pada ayam yang diberi vitamin $C$ sebagai akibat dari pengaruh vitamin $\mathrm{C}$ pada fungsi kelenjar tiroid, yaitu penyerapan iodium lebih besar pada ayam yang diberi 100 ppm vitamin $\mathrm{C}$.

\section{Pengaruh Perlakuan Terhadap Bobot Bursa fabrisius}

Pengaruh suhu ruangan dan pemberian antioksidan yang mengandung vitamin $\mathrm{C}$ terhadap rata-rata bobot bursa fabrisius broiler umur 6 minggu, disarikan dalam Tabel 5.
Upaya penanganan cekaman panas berkaitan dengan immunomodulator, dimana cekaman panas pada ayam broiler mengakibatkan menurunnya bobot organ limposit seperti bursa fabrisius dan tymus (Glick, 1986) menyatakan bahwa organ limpoid seperti bursa fabrisius yang terdapat pada unggas muda berperan dalam memproduksi antibodi dan juga berfungsi untuk konsentrasi vitamin $\mathrm{C}$ kelenjar adrenal. Lebih lanjut dijelaskan bahwa penyuntikan ACTH atau naiknya ACTH oleh stres menyebabkan penyusutan organ-organ limpoid, seperti bursa fabrisius, tymus dan limpa.

Dari Tabel 5 dapat dilihat bahwa pemeliharaan ayam pada suhu tinggi secara nyata $\mathrm{P}<0,01$ menurunkan bobot bursa fabrisius. Bobot bursa fabrisius pada temperatur $20^{\circ} \mathrm{C}$ yaitu $201,119 \mathrm{mg} / 100 \mathrm{gr} \mathrm{BB}$ secara nyata lebih tinggi dari ayam yang dipelihara pada temperatur $26^{\circ} \mathrm{C}$ yaitu $126,780 \mathrm{mg} / 100 \mathrm{gr}$ $\mathrm{BB}$ dan $87,559 \mathrm{mg} / 100 \mathrm{gr} \mathrm{BB}$ pada ayam yang dipelihara pada temperatur $32^{\circ} \mathrm{C}$ dengan ayam yang tidak mendapat cekaman panas. Hasil penelitian ini didukung oleh pernyataan (Aengwanich, 2008; Kusnadi, 2009; Srikhun, 2010) bahwa bobot bursa fabrisius ayam lebih tinggi pada temperatur netral dibanding bobot bursa fabrisius ayam yang mendapat cekaman panas.

Terdapat interaksi antara pemberian antioksidan yang mengandung vitamin $\mathrm{C}$ dalam sari buah mengkudu dengan temperatur lingkungan yang memberikan pengaruh berbeda nyata $(\mathrm{P}<0,05)$ terhadap bobot bursa fabrisius.

Bobot bursa fabrisius pada ayam yang dipelihara pada temperatur $26^{\circ} \mathrm{C}$ dengan

Tabel 5. Rataan Bobot Bursa fabrisius (mg/lo0g BB).

\begin{tabular}{cccccc}
\hline \multirow{2}{*}{$\begin{array}{c}\text { Suhu Ruangan }\left({ }^{\circ} \mathrm{C}\right) / \text { main } \\
\text { plot }\end{array}$} & \multicolumn{4}{c}{ Antioksidan $(\mathrm{ppm}) / \mathrm{sub}$ plot } & \multirow{2}{*}{ Rataan } \\
\cline { 2 - 5 } & 0 & 500 & 1000 & 1500 & \\
\hline 20 & $201,119^{\mathrm{Aa}}$ & $201,867^{\mathrm{Aa}}$ & $200,472^{\mathrm{Aa}}$ & $201,044^{\mathrm{Aa}}$ & 201,125 \\
26 & $126,780^{\mathrm{Bb}}$ & $201,053^{\mathrm{Aa}}$ & $201,325^{\mathrm{Aa}}$ & $202,060^{\mathrm{Aa}}$ & 182,804 \\
32 & $87,559^{\mathrm{Cc}}$ & $152,166^{\mathrm{Bb}}$ & $199,936^{\mathrm{Aa}}$ & $201,686^{\mathrm{Aa}}$ & 160,330 \\
\hline Rataan & 138,486 & 185,028 & 200,578 & 201,596 & \\
\hline
\end{tabular}

Keterangan : Superskrip yang berbeda menurut kolom $(A, B)$ dan baris $(a, b)$ menunjukkan pengaruh berbeda sangat nyata $(\mathrm{P}<0,01)$ 
pemberian 500 ppm antioksidan dalam sari buah mengkudu tidak berbeda dengan bobot bursa fabrisius pada ayam yang dipelihara pada temperatur netral. Sedangkan pada perlakuan temperatur lingkungan $32^{\circ} \mathrm{C}$ dengan peningkatan pemberian antioksidan $1.000 \mathrm{ppm}$ sari buah mengkudu baru dapat menyamai bobot bursa fabrisius dengan ayam yang dipelihara pada temperatur netral. Hal ini berarti semakin tinggi temperatur lingkungan, semakin tinggi kebutuhan antioksidan untuk dapat menghilangkan tekanan pada bobot bursa fabrisius. Hal ini sesuai dengan pernyataan Piliang (2004) suplementasi vitamin $\mathrm{C}$ dalam jumlah banyak diperlukan jika tubuh dalam kondisi stres, pernyataan ini didukung oleh Hornig dan Frigg (1979) bahwa ayam tidak mempunyai kemampuan lagi untuk mensintesis vitamin $\mathrm{C}$ dalam jumlah cukup apabila mendapat cekaman panas.

Pemberian vitamin $\mathrm{C}$ dalam sari buah mengkudu pada broiler dengan suhu netral $\left(20^{\circ} \mathrm{C}\right)$ tidak berpengaruh terhadap bobot bursa fabrisius. Pada ayam broiler yang dipelihara pada suhu ruang $26^{\circ} \mathrm{C}$ pemberian antioksidan $500 \mathrm{ppm}$ yang terkandung pada sari buah mengkudu dapat meningkatkan bobot bursa fabrisius dari 126,780 mg/100g bobot badan menjadi $201,053 \mathrm{mg} / 100 \mathrm{~g}$ bobot badan. Hal ini menggambarkan adanya hubungan antara pemberian antioksidan yang mengandung vitamin $\mathrm{C}$ pada ayam yang mengalami cekaman panas.

Hasil penelitian ini menunjukkan bahwa pemberian vitamin $\mathrm{C}$ pada suhu tinggi menghambat terjadinya involusi bursa fabrisius. Thaxton dan Pardue (1983) juga melaporkan bahwa pemberian vitamin $\mathrm{C}$ mampu mengurangi involusi bursa fabrisius akibat adanya cekaman panas. Pernyataan yang sama dikemukakan oleh Adriyana (2011) yang menyatakan akibat tingginya suhu lingkungan, akan ada pengaruhnya terhadap sel-sel dalam tubuh seperti memicu tubuh untuk mensekresikan antibodi lebih banyak. Semakin sering organ limpoid membentuk antibodi maka akan menyebabkan deplesi dan pengecilan limpoid sehingga beratnya relatif menurun dan akibatnya antibodi yang dihasilkan oleh limpoid tersebut menjadi lebih rendah yang dapat memberikan dampak negatif terhadap kondisi fisiologis dan produktivitas ayam broiler. Sedangkan Aengwanich et al. (2003) dalam pernyataannya bahwa pemberian vitamin C sebanyak 800 $\mathrm{mg} / \mathrm{kg}$ ransum memberikan kekebalan hormonal tertinggi di bawah cekaman panas. Karena pada level ini memproteksi bursa fabrisius dari pengaruh pembebasan hormon glukokortikoid pada ayam broiler selama berada di bawah cekaman panas.

Hasil penelitian ini sesuai dengan hasil penelitian (Aengwanich, 2008; Kusnadi, 2009; Srikhun, 2010) bahwa bobot bursa fabrisius ayam yang mendapat cekaman panas lebih rendah dibanding ayam yang tidak mendapat cekaman panas. Lebih lanjut Aengwanich (2008) menyatakan secara umum bursa fabrisius pada ayam yang mendapat cekaman panas menjadi atropi dan jumlah limpositnya menurun. Fenomena ini disebabkan oleh broiler yang dipelihara pada temperatur lingkungan tinggi, kortikosteron yang berasal pada adrenal kortek akan masuk kedalam sirkulasi darah untuk meningkatkan metabolisme pada ayam broiler. Kortikosteron menyebabkan bursa fabrisius menjadi atropi dan penyusutan bobot bursa fabrisius mengakibatkan menurunnya limposit (Aengwanich, 2009).

Lebih lanjut dijelaskan oleh Al-Ghamdi, (2008) bahwa penurunan bobot relatif organ limpoid bursa fabrisius dan tymus yang dapat dijadikan sebagai indikator imunosupresi sebagai akibat dari perlakuan cekaman panas. Imunosupresi adalah suatu kondisi dimana terjadi penurunan reaksi pembentukan zat kebal tubuh/antibodi sebagai kerusakan organ limpoid. Dengan adanya penurunan jumlah antibodi dalam tubuh maka penyakit akan lebih leluasa masuk dan menginfeksi bagianbagian dari tubuh. Hal tersebut akan menyebabkan gangguan pertumbuhan maupun produksi.

Frankel (1970) menyatakan terdapat hubungan walaupun secara tidak langsung antara kortikosteron dengan ascorbic acid (vitamin C) dalam adrenal. Naiknya ACTH akan menurunkan vitamin $\mathrm{C}$ yang diiringi dengan meningkatnya sekresi steroid adrenal.

Pemberian vitamin $\mathrm{C}$ dapat menekan ACTH sehingga dapat menurunkan sekresi 
kelenjar adrenal berupa kortisol dan kortikosteron dalam sirkulasi darah. Kortisol dan kortikosteron berperan dalam proses glukoneogenesis yaitu merombak non karbohidrat (protein) menjadi energi (glukosa), sehingga pertambahan bobot badan jadi menurun pada kondisi ayam broiler yang mengalami cekaman panas (Guyton, 1983).

\section{KESIMPULAN}

Berdasarkan hasil dan pembahasan berbagai respon yang diamati dapat diajukan kesimpulan, pemberian Antioksidan yang berasal dari sari buah mengkudu (Morinda citrifolia Linn) sebanyak 500 ppm pada ayam yang dipelihara pada suhu $26^{\circ} \mathrm{C}$ dan 1.000 ppm pada suhu $32^{\circ} \mathrm{C}$ dapat mengurangi cekaman panas dan meningkatkan kadar hormon tiroksin dan berat bursa fabrisius serta konsumsi pakan, konversi pakan sama dengan kontrol.

\section{UCAPAN TERIMA KASIH}

Ucapan terima kasih penulis sampaikan kepada Bapak Direktur Jenderal Pendidikan Tinggi, Kementerian Pendidikan Nasional yang telah memberikan dana untuk terlaksananya penelitian ini.

\section{DAFTAR PUSTAKA}

Abu-Dieyeh ZHM. 2006. Effect of chronic heat stress and long-term feed restriction on broiler performance. Int J Poult Sci.5 : 185-190.

Adriyana L. 2011. Suplementasi Selenium dan Vitamin E Terhadap Kandungan MDA, GSH-Px Plasma Darah dan Bobot Organ Limpoid Ayam Broiler yang Diberi Cekaman Panas. Skripsi. Institut Pertanian Bogor. Bogor.

Aengwanich W, P. Sridama, Y. Phasuk, T. Vongpralab, P. Pakdee, S. Katawatin dan S. Simaraks. 2003. Effects of ascorbic acid on cell mediated, humoral immune response and pathophysiology of white blood cell in broilers under heat stress, J. Sci. Technol. 25:297-305.
Aengwanich W dan S. Simaraks. 2004. Pathology of heart, lung, liver and kidney in broilers under chronic heat stress.J. Sci. Technol. 26:417-424

Aengwanich, W. 2008. Pathological changes and effect of ascorbic acid on lesion scores of bursa of Fabricius in broilers under chronic heat stress. Res. J. Vet. Sci., 1: 62-66.

Aengwanich, W. 2009. Comparative ability to tolerate heat between Thai indigenous chickens, Thai indigenous chickens crossbred and broilers by using percentage of lymphocyte. Int. J. Poult. Sci. 7: 1071-1073.

Al-Ghamdi, Z.H., 2008. Effects of commutative heat stress on immunoresponses in broiler chickens reared in closed system. Int.J. Poult. Sci. 7: 964-968.

Al-Sultan , S.I., 2003. The effect of Curcuma longa (Tumeric) on overall performance of broiler chickens.Int.J. Poult. Sci.2 : $351-353$.

Austic, RE. 2000. Feeding Poultry in Hot and Cold Climates. Di dalam MK Yousef, editor. Stress Physiology in Livestock Vol III, Poultry. CRC Press. Florida. pp. 123-136.

Borges, S.A., Fav Da Silva, A. Maiorka, D.M. Hooge and K.R. Cummings. 2004. Effects of diet and cyclic daily heat stress on electrolyte, nitrogen and water intake, excretion and retention by colostomizedmal;e broiler chickens. Int. J. Poult. Sci. 3:313-321. BPS., 2009. Statistik Indonesia. Jakarta, Indonesia.

(BPS) Badan Pusat Statistik. 2009. Statistik Indonesia. Jakarta, Indonesia.

Chan-Blanco, Y., Vaillant, F., Perez, A.M., Reynes, M., Brillouet,.lean-Marc., Brat, P. 2006. The noni fruit (Morinda citrifolia L.): A review of agricultural research, nutritional and therapeutic properties. Journal of Food Composition and Analysis 19:645-654 
Charles, D.R. 2002. Responses to the thermal environment. In: Environment Problem, A guide to solution. Charles, D.A. and A.W. Walker (eds.). Nottingham, United Kingdom, pp. $1-16$.

Chiang, L. and Abdullah, M.A. 2007. Enhanced anthraquinones production from adsorbent-treated Morinda elliptica cell suspension cultures in production medium strategy. Process Biochemistry 42: 757-763

Chong, T.M., Abdullah, M.A., Lai, O. M., Nor'Aini, F. M. and H.Lajis. 2005. Effective elicitation factors in Morinda elliptica cell suspension culture. Process Biochemistry 40: 3397 -3 405

Christensen, K. 1983. The Pools of Cellular Nutrients: Vitamin, In: Dynamic Biochemistry of Animal Production, P. M. Riis, (ed). World Animal Sci. A: Chep. 11, Elsevier, Amsterdam, Oxford, New York, Tokyo.

Cooper, M.A. and K.W. Washburn. 1998. The relationships of body temperature to weight gain, feed consumption and feed utilization in broilers under heat stress. Poult. Sci. 77: 237-242.

Decuypere, E., P. Van As, S Van der Geyten, dan V.M. Darras. 2005. Thyroid hormone availability and activity in avian species : a review. Domest. Anim. Endocrinol. 29:63-67.

Deng, S., West, B.J., Palu, A.K., Zhou, B-N. and Jensen. C.J. 2007. Noni as an anxiolyic and sedative: A mechanism involving its gamma-aminobutyric acidergic effects. Phytomedicine 14: 517 $-522$

Frankel, A. I. 1970. Neurohumoral Control of the Avian Adrenal: A Review. Poult. Sci., 49: 869 .

Fuller, H.L . dan M. Rendom. 1977. Energetic efficiency of different dietary fats for growth of young chicks . Poultry Sci. 56: 549.

Glick, B. 1986. The Effect of Bovine Growth Hormone, Desoxycorticosterone, and
Cortison on the Weight of the Bursa of Fabricius, Adrenal Glands, Heart, and Body Weight of Young Chick ens. Poult. Sci., 39: 1527.

Guyton, A.C. 1983. Fisiologi Kedokteran. Ed. 5. CV. EGC. Penerbit Buku Kedokteran, Jakarta.

Gyorffy, A., A. Sayed-Ahmed, A. Zsarnovszky, V.L. Frenyo, E. Decuypere, and T. Bartha. 2009. Effect of energy restriction on thyroid hormone metabolism in chickens. Acta Veterinaria Hungarica, 57(2): 319-330. Doi: 10.1556/AVet.57.2009.2.12

Heinecke, RM. 2003. Pharmacologically active ingredient noni. http://www.iwr. com/noni juiced/xeronine.html. (21 juli 2005)

Hoffman, Ty. CM, Walsberg, GE. 1999. Inhibiting ventilator evaporation produce an adaptive increase in cutaneous evaporation in mourning doves Zenaida macroura. J Experiment Biol 202:30213028.

Hornig, D., and M. Frigg. 1979. Effect of age on Biosynthesis of ascorbate in chicks. Arch. Gejligelk. 43: 108-112.

Hornig, D., G. Glatthaar, dan U. Moser., 1983. General Aspects of Ascorbic Acid, Function and Metabolism, In: Ascorbic Acid in Domestic Animals, Wegger, I. dan J. B. Anderson, eds. The Scandinavian Association of Agricultural Scientists and The Royal Danish Agri. Society.

Ichsan, M., 1991. Respon Broiler Terhadap Suplementasi Vitamin C. Disertasi. Fakultas Pascasarjana Institut Pertanian Bogor.

Kadam U.S-, Ghosh, S.B., De, S., Suprasanna, P., Devasagayam, T.P.A and Bapat, VA. 2008. Antioxidant activity in sugarcane juice and its protective role against radiation induced DNA dama ge. Food Chemisuy 106: 1154-1 160

Kuczynski, T., 2002.The application of poultry behaviour responses on heat 
stress to improve heating and ventilation system efficiency.Electr.J.Pol. Agric. Univ. 5:1-11.

Kusnadi, E. R. Widjajakusuma. T. Sutardi. P. S. Hardjosworo dan A. Habibie. 2006. Pemberian Antanan (Centella asiatica) dan Vitamin C sebagai Upaya Mengatasi Efek Cekaman Panas pada Broiler. Media Peternakan 29(3): 133 - 140.

Kusnadi, E. 2009. Perubahan Malonaldehida Hati, Bobot Relatif Bursa Fabrisius dan Rasio Heterofil/Limfosit (H/L) Ayam Broiler yang Diberi Cekaman Panas. Media Peternakan 32 (2): 81 - 87.

Laguerre, M., Lecomte, J. and Villeneuve, P. 2007. Evaluation of the abilty of antioxidants to counteract lipid oxidation: Existing methods, new trends and challenges. Progress in Lipid Research 46:244-282

Lin H, H. C. Jiao, J. Buyse, dan E. Decuyper., 2006. Strategies for preventing heat stress in poultry. World's Poult. Sci. 62:71-85.

Matkowski, A. and Piotrowska, M. 2006. Antioxidant and free radical scavenging activities of some medicinal plants from the Lamiaceae. Fitoterapia 77:346-353

Mitzler, D. E., 1977. Biochemistry, The Chemical Reaction of Living Cell. Academic Press. New York, San Fransisco, London.

Mohd Zin, Z.,Abdul-Hamid, A. and Osman, A. 2002. Antioxidative activity of extracts from Mengkudu (Morinda citrifolia L.) root, fruit and leaf. Food Chemistry 78: 227-231

Montoro, P., Braca, A.,Pizza, C. and De Tommasi, N. 2005. Structureantioxidant activity relationship of flavonoids isolated from different plant species. Food Chemistry 92:349-355

Navidshad, B., M. Shivazad, A.Z. Shahneh, danG.Rahimi., 2006. Effects of feed restriction and dietary fat saturation on performance and serum thyroid hormones of broiler chickens.Int. $J$. Poult. Sci. 5: 436-440

Piliang, WG. 2004. Nutrisi Vitamin Vol I. Bogor: Pusat Antar Universitas Ilmu Hayati. Institut Pertanian Bogor.

Puthpongsiriporn U, Scheideler SE, Sell JL, Beck MM., 2001. Effects.of vitamin E and $\mathrm{C}$ supplementation on perfomance, in vitro lympochyte proliferation, and antioxidant status of laying hens during heat stress. Poult.Sci 80:1190-1200.

Quinteiro-Filho, W. M., A. Ribeiro., V. Ferraz-de-Paula., M. L. Pinheiro., M. Sakai., L. R. Sa., A. J. P. Ferreira., and J. Palermo-Neto. 2010. Heat stress impairs perfomance parameters, induces intestinal injury, and decreases macrophage activity in broiler chickens. Poult. Sci. 89:1905-1914.

Rao, Y. K., Geethangili, M., Fang, SH, Tzeng,YM. 2007. Antioxidant and cytotoxic activities of naturally occurring phenolic and related compounds: A comparative study. Food and Chemical Toxicology 10: 1-7

Rastogi, S. C. 1984. Essential of Animal Physiology. Wiley Eastern Limited. New Delhi, Bangalore, Bombay, Calcutta.

Ringer, R. K. 1976. Thiroids, In: Avian Physiology, Third Ed.,P.P. Sturkie, P. P., $(E d)$. Springer-Verlag, New York.

Sahin, N, K. Sahin, dan O. Kücük. 2001. Effects of vitamin $\mathrm{E}$ and vitamin $\mathrm{A}$ supplemantation on perfomance, thyroid status and serum consentrations of some metabolites and minerals in broilers reared under heat stress $\left(32^{0} \mathrm{C}\right)$. Vet Med Czech 46: 286-292.

SAS Institute. 1998. SAS/STAT User's Guide: statistics, Release 7.0 Edition. SAS institute, Inc., Cary, NC.

Schemeiling, S. K. dan C. F. Nockles. 1978. Effect of Age, Sex, and Ascorbic Acid Ingestion on Chicken Plasma Corticosterone Levels. Poult. Sci. 57: 527. 
Sediaoetama, A.D. 1987. Vitaminologi. Balai Pustaka, Jakarta

Siegel, H. S., 1995. Age and Sex Modification of Responses to Adrenocorticotropin in Chickens 2. Change in Adrenal Cholesterol and Blood Constituent Levels. Poult. Sci. 41: 311.

Srikhun, T. W, Aengwanich and W. Kongbuntad. 2010. Effects of Polyphenols Extracted from Tamarind (Tamarindus indica L.) Seed Coat on Body Weight, White Blood Cells, Bursa of fabricius and NDV-HI Titer of Broilers under Chronic Heat Stress.

Steel, RGD dan Torrie JH. 2005. Prinsip dan Prosedur statistika Suatu PendekatanBiometrik. Ed ke-2 cetakan
Keempat. Jakarta : Gramedia Pustaka Utama.

Syamsuhidayat, SS dan Hutapea JR., 1991. Inventaris Tanaman Obat Indonesia Badan Litbang Kesehatan, Depkes RI.

Thaxton, J. P. dan S. L. Pardue. 1983. Ascorbic Acid and Physiological Stress, In: Ascorbic Acid in Domestic Animals, Tagwerker, F. J, J. Moustgaard, dan J. E. Anderson, Eds. F. Hoffman-La Roche \& Co. Ltd. The Royal Danish Agricultural Society.

Yi, M., C. Xiaoqiang, L. Qiang, A. Xiaorong and C.Yongfu. 2009. effect of thyroid hormone on the gene expression of myostatin in rat skeletal muscle. AsianAust. J. Anim. Sci. 22 (2): 275 - 281. 